\title{
Сидерякова Н.В.
}

\section{Трудовое обучение и воспитание, профессиональная ориентация учащихся в СССР в 1970-1990-х гг.}

\author{
Sideryakova N.V. \\ Labor education and training, professional orientation \\ of students in the USSR in 1970-1990-ies.
}

В статье раскрыты основные направления развития советского образования в 1970-1990-е гг., в плане трудового воспитания и обучения учащихся школ, а также формах профориентационной работы и воспитания у молодежи сознательного отношения к труду и общественной собственности

Ключевые слова: трудовое воспитание, профориентационная работа

\section{Сидерякова Надежда Васильевна}

Преподаватель

Чебоксарский электромеханический колледж

Чувашская Республика, г. Чебоксары, ул. Ленина, 9

\begin{abstract}
The article deals with the main directions of development of the Soviet education in 1970-1990ies., In terms of labor education and training in schools, as well as forms of career guidance and education of the youth conscious attitude toward labor and public property
\end{abstract}

Key words: labor education, vocational guidance work

\section{Sideryakova Nadezhda Vasilievna \\ Teacher \\ Cheboksary electromechanical college \\ Chuvashia republic, Cheboksary, \\ Lenin st., 9}

В Советском Союзе под трудовым воспитанием понимался целенаправленный процесс формирования у подрастающего поколения готовности трудиться, стремления и умения практически участвовать в построении коммунистического общества, а также формирование коммунистического отношения к труду. Трудовое воспитание было направлено на успешное освоение молодежью трудового опыта, включавшего знания, умения и навыки трудовой деятельности, нравственное отношение к труду и трудящемуся человеку, на всестороннее развитие личности [1, с. 123]

Конституция СССР закрепляла гарантированное право на труд, право на выбор профессии с учетом потребностей народного хозяйства и способностей каждого человека. Вместе с правом на труд в Программе КПСС и в Конституции СССР была подчеркнута и обязанность советских граждан добросовестно трудиться и соблюдать трудовую дисциплину: «каждый трудоспособный человек должен участвовать в создании тех средств, которые необходимы для его жизни 
и деятельности, для благосостояния общества» [2, с. 242]. Труд как общественная необходимость должен был стать потребностью советского человека, делом его чести. Именно поэтому «в центр воспитательной работы партия ставила развитие коммунистического отношения к труду у всех членов общества» [3, c. 98].

В рассматриваемый период в школах были достигнуты успехи в совершенствовании трудового воспитания и обучения, а также в работе по профессиональной ориентации школьников. Исходя из этих показателей перед народным образованием были поставлены следующие задачи: увеличить подготовку квалифицированных рабочих в профессионально-технических учебных заведениях и подготовить в течение 1971-1975 гг. в профессионально-технических учебных заведениях не менее 9 млн. квалифицированных рабочих для всех отраслей народного хозяйства. Для решения этих задач были выработаны пути: «осуществить переход ко всеобщему среднему образованию; усилить работу по профессиональной ориентации учащихся с учетом склонностей молодежи и потребности народного хозяйства в квалифицированных кадрах» [4, с. 115].

Органам народного образования предлагалось провести систематическую работу по изучению склонностей учащихся 8-х классов, оказывать помощь в выборе специальности для дальнейшего обучения, с учетом пожеланий и возможностей учащихся и их родителей», а педагогическим коллективам школ следовало проводить широкую разъяснительную работу по популяризации профессионально-технических учебных заведений, знакомить учащихся с профессиями, по которым ведется подготовка в училищах, способствовать направлению в профтехучилища лучшей части учащихся, окончивших восьмые классы, обратив особое внимание на оказание всемерной помощи желающим завершить среднее образование в средних профессионально-технических учебных заведениях» [5, с. 95].

В исследуемый период также остро стояла проблема подготовки молодежи к практической деятельности, к труду в сфере промышленного и сельскохозяйственного производства. Ее решение учительство связывало с поиском новых направлений и форм в профориентационной работе с учащимися с учетом потребности народного хозяйства в квалифицированных кадрах. Трудовое обучение в старших классах предлагалось сочетать с овладением массовыми профессиями, требующимися для материального производства и непроизводственной сферы. В школах действовали советы по профориентации, в состав которых, как правило, входили родители, представители базовых предприятий, администрации школы.

Учителя совместно с членами совета проводили работу по профориентации. Здесь были и встречи с производственниками, и экскурсии на фабрику, и создание уголков и стендов по профориентации, и изучение истории предприятия. Улучшалась постановка трудового воспитания [6, с. 2].

Характерной особенностью коммунистического воспитания было воспитание коммунистического отношения к труду и общественной собственности. «Нужно чтобы дети, подростки, юноши воочию увидели, что такое рабочий 
класс, что такое труд крестьянина на современном этапе, как много надо знать, чтобы быть достойными преемниками старшего поколения» [6, с. 3].

Важнейшей формой профориентационной работы, привития учащимся любви к сельскохозяйственному труду были ученические производственные бригады, которые действовали непосредственно в сфере материального производства.

Традицией трудового воспитания советской школы было привлечение старшеклассников к трудовому участию в народном хозяйстве. В этих целях летом 1978 г. в стране широко было развернуто движение ученических производственных бригад, получившее поддержку в школах города и района. Трудовые бригады старшеклассников ремонтировали школьную мебель, работали на полях колхозов и совхозов на обработке, прополке и уборке лука и свеклы.

В партийно-правительственном постановлении «Об улучшении трудового воспитания, обучения, профессиональной ориентации школьников и организации их общественно полезного производительного труда» (1984) [7, с. 14] получили дальнейшее развитие, углубление и конкретизация основных задач учебно-производственных комбинатов в соответствии с современными требованиями к обучению и воспитанию учащихся: трудовое, профессиональное на политехнической основе обучение учащихся; организация общественно полезного производительного труда школьников, воспитание у них сознательного отношения к труду и общественной собственности; проведение профориентационной работы с учащимися города. Перечисленные задачи, возможно, было решить только при совместных усилиях УПК и промышленных, строительных, транспортно-торговых предприятий и организаций.

В рассматриваемый период в школах города и района были достигнуты большие успехи в совершенствовании трудового воспитания и обучения, благодаря принятию постановлений о возможности сочетания обучения с производительным трудом. Школа должна была подготовить высококвалифицированных специалистов, в которых нуждалось народное хозяйство страны. В этих целях в практику школы стали активнее вводится уроки труда, а также работа на опытных и учебных участках. Усиливается связь школ с промышленными предприятиями, цехами, колхозами и совхозами, на которых учащиеся получали трудовые умения и навыки. Советская школа была призвана воспитывать у учащихся глубокое понимание необходимости труда, потребности трудится, формировать у них трудовые умения и навыки, готовить учащихся к самостоятельной трудовой жизни, сознательному выбору профессии.

\section{Список используемых источников:}

1. Логинова В.И., Саморукова П.Г. Дошкольная педагогика. М.: Педагогика, 1983. 312 c.

2. Кукушкин Ю.С., Чистяков О.И. Очерк истории Советской Конститущии. М.: Политиздат, 1987. 367 с.

3. Материалы ХХV съезда КПСС. М.: Политиздат, 1976. 256 с.

4. Коммунистическая партия Советского Союза в резолюциях и решениях съездов, конференций и пленумов ЦК. Институт марксизма-ленинизма при ЦК КПСС. Т. 13. М.: Политиздат, 1987. 510 с.

5. Скаткин М.Н., Костяшкин Э.Г. Трудовое воспитание и профориентация школьников. М.:

Просвещение, 1984. 191 с. 
6. Школа на новом рубеже // Новая Кама. 1971. 1 сентября. № 141. С. 2-3.

7. Паначин Ф.Г., Колмакова М.Н., Равкин З.И. Очерки истории школы и педагогической мысли народов СССР (1961 - 1986 г2.). М.: Педагогика, 1987. 416 c.

(C) 2015, Сидерякова Н.B.

Трудовое обучение и воспитание, профессиональная ориентация учащихся в СССР в 1970-1990-х г2.
(C) 2015, Sideryakova N.V.

Labor education and training, professional

orientation of students in the USSR in 1970-1990-ies. 